2. Моніторингове дослідження гендерного балансу в онлайн-3МІ. Третій квартал 2020-го. Інститут масової інформації: веб-сайт. URL: https://imi.org.ua (дата звернення: 28.01.2021).

3. Жінки. Мир. Безпека: Інформаційно-навчальний посібник 3 гендерних аспектів конфліктів для фахівців сектору безпеки / Ковальчук Л.Г. та ін.; за ред. Ковальчук Л.Г., Левченко К.Б. Київ, 2017, 264 c.

4. Про забезпечення рівних прав та можливостей жінок і чоловіків: Закон України від 8 вер. 2005 р. № 2866-IV. URL: http://zakon5.rada.gov.ua/laws/show/2866-15 (дата звернення: 19.02.2021).

5. Мельникова О.С Особливості гендерного балансу в мас-медіа. Актуальні проблеми науки та освіти: зб. матеріалів XX підсумкової наук.-практ. конф. викладачів МДУ 2 лют. 2018 р. Маріуполь: МДУ, 2018. C. $247-249$.

6. Риженко Л. Тенденції розвитку гендерного питання на сторінках періодичної преси. Образ 2016. Вип. 2. С. $98-103$.

7. Бровченко С. П. Особливості висвітлення гендерної проблематики в українських медіа. Сучасні світові тенденції розвитку науки та інформаційних технологій: зб. матеріалів Міжнар. наук.-практ конф. Одеса : ГО «Інститут інноваційної освіти», 2018. С. 119 - 123.

8. Мельникова О.С. Особливості проведення гендерних досліджень у медіа. Образ 2017. Вип. 2. С. $56-65$.

\title{
DOI https://doi.org/10.30525/978-9934-26-042-1-2
}

\section{МЕДІАКУЛЬТУРА У ФОРМУВАННІ Й ТРАНСЛЯЦЇ̈ СОЦІОКУЛЬТУРНИХ ЦІННОСТЕЙ СУСПІЛЬСТВА}

\author{
Денисюк Ж. 3. \\ доктор культурології, \\ доиент кафедри гуманітарних дисииплін \\ Національна академія керівних кадрів культури і мистецтв \\ м. Київ, Украӥна
}

Інформаційно-комунікативні технології та породжувані ними численні медіа-комунікації утворили покоління так званих «нових медіа», які грунтуються на цифровому відтворенні інформації. Вони стали не лише засобами виконання безпосередньо комунікативних та 
інформаційних функцій, але й спричинилися до формування культурних феноменів та практик. Обумовлюючись логікою цивілізаційного й технологічного розвитку, засоби медіа-комунікації перетворилися на самостійну сферу із власними семіосмислами і значеннями, які визначають вектори розвитку практично всіх сфер соціуму, в том числі аксіосферу.

Еволюціонувавши в процесі цивілізаційно-технологічного розвитку, сучасні медіа вийшли за межі суто комунікативної функції, створивши окреме медіа-середовище, що надає підстави трактувати його як «третю природу», де головним відмінним від реальності фактором виступає віртуалістика [3, с. 7]. У результаті це спричинило породження окремого сегменту медіакультури, яка, окрім безпосередньо самих засобів комунікації, включає в себе різні взаємодії та взаємовпливи об'єктів і суб'єктів, що утворюють систему інформаційно-культурних відносин. Специфіка медіакультури визначається іï семіотичною природою і технічними можливостями засобів іiі реалізації: висока інформаційна ємність, легкість і переконливість чуттєвого (образного) сприйняття, домінування продуктивних можливостей над репродуктивними, швидкість і широта трансляції та тиражування, масовість і доступність формують соціокультурні функції медіакультури.

3 появою в інформаційному суспільстві сфери медіакультури, остання фактично перетворилася на потужну систему, яка перебрала на себе функції ретрансляції та продукування культурних взірців та значень. Окрім цього, відзначається величезний маніпулятивний вплив сфери медіа на реалії буття, 3 системою міфології, здатною продукувати «певні цінності без їхнього критичного осмислення» $[91,11]$. У процесі такого медіа-продукування ціннісних смислів і значень та за допомоги використання художніх засобів виразності відбувається як акумулювання традиційних культурних смислів, так і пошук нових смислів та цінностей.

Медіа - частина соціального простору, за допомоги якого воно репрезентує самого себе. Організація медіа-простору в єдину мережу і взагалі його майбутнє однозначно пов'язане з розвитком інтернету. Якщо медіа-простір загалом є репрезентацією соціального простору, то інтернет в інформаційному аспекті - репрезентація самого медіапростору [1, с. 92]. Простір медіакультури існує не тільки на основі виробництва й передачі повідомлень, але й поширення певних ідей, образів, які часто генеруються соціальними інтересами, перш за все, політичними та економічними, що належать різним спільнотам, групам та особам, які мають доступ та можуть впливати на такі процеси, та будується на ідеологічних та емоційних очікуваннях аудиторії. 12 
У зв'язку з цим, сучасні медіа $є$ не просто системою ЗМІ чи каналів комунікацій, а цілком конкретною і владною матрицею, яку утворюють культурні та інформаційні монополії [2, с. 73].

Транслюючи систему поглядів на світ, що структурують інтереси й цінності суспільства, ЗМК формують особливу медійну аксіосферу умовну сферу мас-медійної інформації, що репрезентує ціннісні домінанти суспільства й здійснює аксіологічний вплив на реципієнтів. Трансляція цінностей відіграє важливу роль в комунікації, яка відображає основні культурні цінності, притаманні тому чи іншому народу. Медіа задають певні аксіологічні моделі поведінки, 3 якими реципієнти співвідносять свої моральні принципи, ціннісні орієнтири і навіть виробляють стереотипи мислення під впливом трансльованих зразків.

Попри це, завдяки своїм внутрішнім характеристикам, медіакультура виступає універсальною формою соціокультурної взаємодії, що сприяє формуванню нової соціокультурної морфології (і міфології), структурує комунікативні процеси в новий порядок, транслюючи й передаючи змісти, знаки, образи індивідам та соціальним групам.

Аксіологічна складова комунікативних процесів на різних рівнях соціального відтворення $\epsilon$ визначальним індикатором духовного стану суспільства, що дозволяє говорити про його життєздатність у напрямках майбутнього розвитку. Ціннісний компонент комунікативних відносин стає похідним від системи суспільних цінностей, які виробляються в процесі розвитку тієї чи іншої соціокультурної форми і закріплюються в соціальних нормах. Одним із найважливіших детермінантів аксіологічної комунікації $є$ соціокультурний простір, адже будь-яке повідомлення породжується мовцем і слухачем у конкретних ситуаціях, у межах широкого соціокультурного контексту. Цінності завжди обумовлені тим або іншим соціальним контекстом, вони, безперечно, мають соціальний характер. Це обумовлено тим, що всі ціннісні орієнтири формуються на основі існуючої суспільної практики, індивідуальної діяльності людини і в межах певних конкретно-історичних суспільних відносин та форм спілкування людей. Поява таких структур, як аксіологічні матриці, $\epsilon$ необхідною умовою взаємодії соціуму із навколишньою дійсністю i нормалізацією відносин всередині самого соціуму. Будучи породженням життєдіяльності конкретного соціуму, соціальні цінності відображають в собі основні риси цієї життєдіяльності в знятому вигляді.

Фактично на сьогодні медіакультура $\epsilon$ поліфункціональним універсальним феноменом, який створює власне культурне та комунікативне середовище на основі особливих символічних форм ціннісносмислового вираження змісту. 


\title{
Література:
}

1. Дурманенко О. Віртуальний простір комунікаційних мереж Інтернету як елемент конструювання соціальної реальності. Науковий вісник Східноєвропейського національного університету імені Лесі Українки. Філософські науки. 2013. № 11. С. 89-94.

2. Кириллова Н. Б. Медиакультура: от модерна к постмодерну. Москва: Академический проект, 2005. 448 с.

3. Ороховська Л. А. Медіакультура в контексті цивілізаційного розвитку: автореф. дис... д-ра філос. наук: 09.00.03 - соціальна філософія та філософія історії. Київ, 2015. 34 с.

\section{DOI https://doi.org/10.30525/978-9934-26-042-1-3}

\section{КІБЕРКУЛЬТУРА: ПРОБЛЕМА ІДЕНТИФІКАЦЇ̈ ОСОБИСТОСТІ}

\author{
Сардарян К. Г. \\ доиент кафедри видавничої справи та редагування \\ Інститут журналістики
}

Київського начіонального університету імені Тараса Шевченка

\section{Сардарян Д. А.}

студент

Киівський інститут інтелектуальної власності та права

Національного університету «Одеська юридична академія»

м. Київ, Україна

Кіберкультура посіла важливе місце в житті сучасного суспільства. Сучасна масова віртуальна культура пов'язана 3 розвитком цифрових технологій, їх усебічним проникненням та залученням в сфери особистого життя, соціальної, виробничої, ділової діяльності членів суспільства. Сьогодні кіберкультура вийшла за межі віртуальності, стаючи невід'ємною частиною ірреальної реальності, можна говорити про зв'язок та активну суспільну взаємодію на межі реального та віртуального просторів. 3 розвитком інформаційних технологій межа між реальністю та віртуальністю зменшується. Сьогодні віртуальна реальність - норма, яка полегшує реалізацію ділової діяльності, професійної сфери та проведення дозвілля. Діджиталізація призвела до 